\title{
Institutional Resistance to Religious Diversity in Prisons: Comparative Reflections Based on Studies in Eastern Germany, Italy and Switzerland
}

\author{
Irene Becci
}

Published online: 29 April 2014

(C) Springer Science+Business Media New York 2014

\begin{abstract}
This article explores the way in which prison institutions resist to religious diversity in three national contexts: Italy, Germany and Switzerland. The author observes a phenomenon which contributes to this resistance and that she calls 'institutional neutralisation of Christianity'. Although they are secular state institutions, prisons' profound Christian heritage impacts at a variety of levels beyond their chaplaincies. With the help of Durkheim's and Foucault's contributions on punishment, the author identifies in the punishment-rehabilitation complex a mediator of this Christian heritage contributing to its institutional neutralisation. An illustration of these theoretical insights by empirical observation concludes the article.
\end{abstract}

Keywords Prison chaplaincy $\cdot$ Durkheim $\cdot$ Foucault $\cdot$ Minister $\cdot$ Secularisation $\cdot$ Religious diversity · Germany · Switzerland · Italy

\section{Introduction}

Classical social sciences literature on religion has highlighted the effects of secularisation in terms of the reduced significance of ecclesiastical authorities in social life, the fading legitimacy of Christian moral doctrines on daily life, as well as the falloff in the formal membership of most religious communities. ${ }^{1}$ More recently, close attention has been paid to the dynamics associated with individualisation and globalisation that brought about unprecedented diversification of the religious landscape and, in some contexts, even revitalised the religious scene (see Casanova in Becci, Burchardt, and Casanova 2013). The joint effect of these processes of secularisation and religious pluralisation has been particularly apparent in state institutions.

The reactions to these processes in terms of institutional change have been very diverse, with great variance both across countries and according to the type of institution. I have

\footnotetext{
${ }^{1}$ In short, as Peter Berger states, secularisation is 'the process through which parts of society and of culture are subtracted from the domination of religious institutions and symbols'. The Sacred Canopy, 1990, p. 107.
}

I. Becci $(\bowtie)$

Institute of Social Sciences of Religion, University of Lausanne, Lausanne, Switzerland

e-mail: irene.becciterrier@unil.ch 
investigated this issue in the context of prisons in Germany, Italy and Switzerland and have found different sorts of regulation strategies. ${ }^{2}$ In this article, I will concentrate on a common regulation strategy, that of institutional neutralisation of Christianity and resistance to religious pluralisation. The warden at a prison located in the French-speaking part of Switzerland (with about 80 detainees, including 50 women) expressed the essential content of this strategy as I talked to him on the phone in 2008. I asked him about the management of religious diversity in his establishment, and he told me the following:

In our prison, about two-thirds of prisoners are Christians or atheists and many of the remaining third are Muslims... we sought an imam and we found one. Now he visits on Fridays for prayers. The first one we found did not want to leave his keys at the entrance and did not return... Our Muslims are surprisingly tepid... Our two chaplains, one Catholic and one Protestant, are of very good quality [Laughter]. They are-I would say - omni religious, they mediate for other religions. We also found a rabbi. When we need him, we call him. If we need one, we also have a Buddhist representative.

Four parts of his account are particularly revealing: first, the warden's estimation of the number of Christian detainees in his prison was probably overstated or optimistic ${ }^{3}$; second, when he mentioned Muslims, he had no hesitation in finding them suspicious, and took for granted (since he offered no explanation) that I would implicitly understand and agree. The prefix 'omni', which he used to refer to the chaplains' position as universal actors, is particularly telling. The term 'omni' refers to Christian 'universality', whereas the 'other' religions are treated on an individual basis upon request from inmates. Finally, this warden recognised the religious diversity within his establishment, but seemingly felt no need to make structural changes to extend the provision of spiritual care to properly incorporate care for non-Christian inmates.

The question I intend to tackle in this article is how to understand this neutralisation ${ }^{4}$ of Christianity and the institutional resistance — or inertia, at least - in relation to recognising the new challenges of religious diversity. My claim is that, despite being seen as secular state institutions, prisons in the three countries studied - Italy, Germany and Switzerland - continue to carry and have retained their heritage for reasons that the theoretical literature on prisons, in particular Durkheim and Foucault, has clearly identified. In this article, I re-visit this theoretical literature in order to offer an understanding of the existing institutional resistance towards religious diversification in prisons. ${ }^{5}$ I concentrate on two concepts, punishment and rehabilitation, which are at the core of prison institutions.

\section{The Historicity of Religion's Place in Prison}

Until the last century, churches in the three countries examined in this article were in charge of most educational, healthcare and civic functions. The birth of specialised secular institutions

\footnotetext{
${ }^{2}$ Studies in greater depth were conducted on two prisons in each country, focusing on Central Italy, Eastern Germany and Western Switzerland. Please refer to Becci 2011, Becci et al. 2011 and Becci 2012 for details on methodology. I concentrate here on the theoretical issues to illuminate a selection of my findings.

${ }^{3}$ The tables reproduced below make this clear.

4 That is, a sort of naturalisation, to use Mary Douglas' (1987, p. 52) term.

${ }^{5}$ In my understanding, the notion of religious diversity refers to qualitative diversity within the same religious tradition. Examples would include the phenomenon of hybridisation of cultural and spiritual aspects, which is particularly visible in urban areas, and the appearance of new practices and organisations, some of which may not have been widely known or may not have been present in the Western world until recently, and which may have - to some extent - been imported during periods of migration. Religious diversity derives from the new social circulation of religious discourses, belongings, symbols, ideas and practices that has followed from the process of globalisation (Berger 1995, Knott 2009, Yuval-Davis 2011).
} 
(schools, hospitals, orphanages, prisons and retirement homes, for example) meant that Christian denominations saw their primacy fade, and today, their presence in these same institutions has seemingly been reduced to the fulfilment of a chaplaincy role. In Germany, church and state view each other as collaborators in the prison domain. In Italy, church and state are legally separate, but the strong links established through the concordats offer a series of conditions which favour the presence of a Catholic prison chaplaincy (see Ruffini 1975). The Swiss case is a hybrid, marked by cantonal differences, but chaplaincies are generally managed by the Protestant and Catholic churches. Beyond these differences, common patterns emerge in the study of the prisons in these three countries. In all of them, prisons have a strong Christian heritage which is visible from both an ideological point of view, particularly in the notion of punishment, and from an organizational point of view, in the manner in which chaplaincy is integrated in the prison structure. In the prisons studied for this article, the process of secularisation is apparent, in that Christianity no longer plays a pivotal role in the prison systems. This is, at least in part, due to the diversification of services that detainees may avail of (therapy, cultural or social activities, case management, etc.). However, the analysis also shows that this secularisation has not entailed the elimination of religion but rather the transformation of its institutional role. The process of secularisation has gone hand in hand with the establishment of a system of rights which guarantees freedom of belief and worship for detainees, regardless of religious orientation. In recent years, the prisons in question have found local and ad hoc solutions to the new religious diversity, as illustrated by the quotation above. They have modified their models of spiritual assistance to reflect the greater levels of religious diversity without questioning the specific position of the Christian chaplaincy as such.

Hence, chaplaincy is only the most visible aspect of religion's role. As I consider religion to be a total social fact (Mauss 1950) which is marked by the notion of transcendence, the role of religion in the prison context will be approached in an inductive way through multiple perspectives. The concept of religion implies not only a collective aspect (system of symbols) but also an individual aspect (expressed in terms of religiosity). These two aspects can be found in religious actions which involve communication, performance and togetherness, as well as rights and legislations. The notion of religion adopted for the purposes of this paper therefore goes beyond the scope of the chaplaincy and assigns all necessary significance to the juncture between the religious and the cultural (Amiraux 2012).

As I shall argue in what follows, through the process of institutional neutralisation, the established religion has also become universal, and thereby holds a unique position in relation to all other religions. However, to understand this neutralisation in terms of privilege would be misleading. In all three countries, chaplaincies must meet the expectations of established churches, state institutions and prison populations. ${ }^{6}$ This can often lead to tensions which affect chaplains' day-to-day work in a variety of ways. On the one hand, they are expected to act in a universalistic way towards detainees as well as towards staff; on the other, they are supposed to be religiously committed actors who perform symbolic rituals. In post-socialist German areas, this tension is further strained by the unusual situation. As a matter of fact, while Protestants and Roman Catholics account for less than a quarter of the population, their churches have been responsible for the prison chaplaincy since the demise of the GDR.

\footnotetext{
${ }^{6}$ These expectations concern, for instance, their professional skills or the degree of their involvement in the institutional rehabilitation programme for inmates. See also Becci 2011 for a comparative analysis of chaplaincy regulation in the three countries.
} 
Moreover, the state has assigned religion a specific function within prisons by separating it from security issues to some extent. ${ }^{7}$ The role of prisons today is indeed twofold. On the one hand, prisons are supposed to protect society from criminals by locking them up and punishing them through confinement. However, it also tries to rehabilitate them. This process of differentiation between the role of punishment, on the one hand, and that of rehabilitation, on the other, has an effect on prison chaplaincy. Since prisoners have been guaranteed religious freedom, chaplaincy is no longer part of the punishing process. Nevertheless, being part of the prison institution, it must constantly relate to the aim of punishment and be repositioned.

Historically, one way for secular state institutions to neutralise Christianity has been to deal with religion as relating to a specific territory and as part of individuals' private lives. ${ }^{8}$ I conducted some fieldwork at a prison in Switzerland which, until the end of the 1950s, was contractually bound to the local Bethany deaconesses. When their involvement with the prison came to an end, the provision of religious assistance became an individualised spiritual service, paid or voluntary, separate from other social and cultural services. Nowadays, the level of religious diversity challenges both the territorialisation and the individually private characterisation. Religious communities today are becoming increasingly de-territorialised - in situations of diaspora, for example - and conceive of religious action as bridging the public-private divide. Empirical studies have shown that this change meets resistance at different levels of society. ${ }^{9}$ Therefore, in order to analyse institutional reactions to the increasing religious diversity of prison populations, we must also challenge ideas concerning the structural differentiation between the religious and the secular in public institutions.

\section{Religion in the Punishment-Rehabilitation Complex}

Prison has long been considered an interesting topic on account of two special features-its punishment and rehabilitation functions - as well as its overall character. In the first empirical sociological studies on prisons which were carried out in the 1940s and 1950s in the USA ${ }^{10}$, prison populations were considered enclosed entities, with their own social structures. The effect of incarceration on inmates was studied as a cause of recidivism. Erving Goffman's proposal (1968) states that prisons should be treated as total institutions made perfect sense in the intellectual context of the time. Such authors took the secularisation process for granted and, if they paid any attention to religion in their studies, it was subsumed within the examination of the total institution's impact on inmates' religiosity.

In the following decades, the manner in which prison was analysed became more diverse, and a greater variety of perspectives started to be taken into account. ${ }^{11}$ The focus of attention expanded beyond prisoners to include staff and their interactions, ${ }^{12}$ as well as the relation between the prisons and the outside world. However, alongside schools, hospitals and retirement homes, the prison system continued to be viewed as a completely secularised space, and religion no longer seemed to have a role to play.

\footnotetext{
${ }^{7}$ In Italy, for example, chaplains have not served on disciplinary boards since 1975. As in the other two countries considered here, they can still be members of advisory boards on prison treatment and can exert influence on the standards of the rehabilitation model.

${ }^{8}$ cf. Tschannen 1992.

${ }^{9}$ Stolz and Baumann (2009) have documented that in Switzerland, the more privately members of new religious communities practice, the more likely their religion is perceived to be legitimate.

${ }^{10}$ Clemmer 1958 [1949], Sykes 1958.

${ }^{11}$ For Switzerland, see (amongst others) Maeder 1995.

12 'The carceral relationship', to quote Corinne Rostaing (2006).
} 
Recent research in the field has followed from the premise that prisons are not as clearly separate from society as most of the earlier studies would have led us to believe. A 'diffusionist' approach (Combessie 2009) emphasises the link of prisons with society and criminal policies (Garland 1990 and Garland 2001a, b, Melossi 1990, Wacquant 1999). Thus, the modes of political regulation of migration and social deviance as well as decisions relating to economic policy clearly have a direct impact on the type of the religious diversity present in correctional institutions. But even in the studies that adopt this approach, religion never plays more than a marginal role. Therefore, we need to work out how to focus on religion while adopting a diffusionist approach to the prison. Today, the sociology of prison takes into account the social context of the prison institution and how it is linked to society, and examines the role of the enduring historical links with Christianity, but also investigates the new religious diversity in prisons.

I will therefore review some crucial theoretical aspects that have strongly influenced prison studies in order to provide some perspective on the notion of religion within such studies. I will focus on some of Emile Durkheim's and Michel Foucault's reflections on punishment, and how them relates to religion and secularity. This will allow me to frame my empirical findings further along. In fact, although prisons are no longer exclusive about punishment, the concept still weighs heavily upon the prison experience. Beyond all the structural differentiation that has allocated a (specific and clearly restricted) place and role to religion in the prison context, religion continues to be mediated through such notions as punishment and rehabilitation. The day-to-day organisation of prison life is laid out according to principles of retribution and punishment.

Throughout modernity, the theories used to justify punishment have oscillated between two referential poles. ${ }^{13}$ One is the so-called absolute theory of sentence, which views retaliation as the aim of punishment necessary to re-balance the social order. Punishment in itself is an aim. Whether this re-balancing is achieved or not is, in this view, defined by the degree of satisfaction of the victims of the crime, that is, ultimately, of society. The object of punishment is in this case the crime itself, the act that harmed and thereby upset the balance of social order. In order for social order to be reestablished, therefore, a 'balancing act' must take place; the perpetrator whose action has endangered the societal cohesion must be symbolically or physically 'removed'. As I will show in the next section, Durkheim is probably the paradigmatic thinker of the social dynamics behind this process.

The second pole is defined by what is called the 'relative theory of punishment'. Crime is no longer seen as symbolical of the violation of social order, and religion is reduced to performing a technical and utilitarian role contributing to the fulfilment of the pre-set target of imprisonment. Punishment, from this perspective, is viewed as a means to achieve certain specific aims, for instance, to have a deterrent, preventive or resocialising effect. The aim of punishment is to inculcate in the minds of actual and potential criminals that illegal activity is not appreciated and should not be repeated, and to show them how they should behave instead. Foucault most persuasively theorised on this intrusion of power into the mind of individuals by concentrating on the emergence of disciplinary institutions in the nineteenth century. A closer discussion of Foucault's writings on religion and penitence will follow the section on Durkheim. These two authors' contributions enable us to consider the inclusion of religion in the social punishment and rehabilitation processes, and to historically trace the process of universalisation.

${ }^{13}$ Amongst others, cf. Santoro 2005 and Wiesnet 1980. 
As he wrote in his masterpiece, The elementary forms of religious life (Durkheim 1991), Durkheim considers religion to be an essential element of all societies because it is fundamentally linked to social cohesion. Religion creates social ties: its social form may change over time, but its basic function remains intact. Durkheim's views on this social-religious overlap are one of the most widely known features of his work, and are clearly expressed in the following quotation:

If religion has engendered all that is essential in society, this is because the idea of society is the soul of religion. ${ }^{14}$

While Durkheim envisaged the weakening of social bonds, ideally the 'idea of society' - as a God-like entity ${ }^{15}$ - should be present at all times in social life. He writes, therefore, that 'religion seems destined to transform rather than disappear'. ${ }^{16}$ Religion can survive modernisation in other forms, such as in the state, for instance. According to Durkheim, in modernity, the force that unites people is provided by the secular state. It mobilises the passions and emotions necessary to achieve a sort of collective consciousness. The Durkheimian concept of punishment ${ }^{17}$ is linked to this idea. Durkheim noted that punishment is not merely the result of an interaction involving just two parties (the offender and the victim) but is, in fact, a social reaction on a broader scale to the re-adjustment of broken social ties. Since everyone is part of society, when an offence is committed against persons within the social order, social ties or social rules are broken, and common sentiments arise against the offender. To quote Durkheim, 'the only characteristic common to all crimes is that they consist [...] [of] acts universally disapproved [of] by the members of each society'. ${ }^{18}$ Durkheim displays a positive understanding of the function of punishment: public or social punishment is a response to attacks on moral solidarity, to the imperilment of the collective consciousness; it serves to reaffirm and strengthen social ties. Punishment ensures that criminals are aware of the (largely symbolic) gravity of their actions, not so much for the actual victims of crime but more for society as a whole, which, as stated previously, overlaps with the conception of God and the content and target of religion. Religion, in Durkheim's sense, and punishment are not opposed to one another rather the latter is there to preserve the former, i.e. society. Other authors have emphasised the disintegrative potential of religions. George Herbert Mead (1918) had a particularly interesting approach in this context, and responded to Durkheim's vision of punishment by positing the opposite. According to Mead, the passionate feelings that can be stirred up in the collective consciousness by an offence can indeed lead to the constructive responses suggested by Durkheim, but such powerful sentiment can also have ramifications. Through analysis of the psychological dynamics of public responses to criminal offenders, Mead emphasised that the downside to the strengthening of social cohesion is an increase in the instinctive public hostility towards offenders. For him, being part of a particular society involves the conscious exclusion of others. The mechanism of punishment justifies precisely this perception of the 'other' as a threat, and provides an equally strong - if not stronger - tie to the community than the bond established by simply being part of it. In the words of David Garland,

\footnotetext{
${ }^{14}$ Durkheim 1991, p. 697.

${ }^{15}$ Durkheim (1991) uses the term God to refer to something that people conceive of as superior and which they depend upon. See also Poggi 2000. However, this does not imply a vision of society as a monolithic entity, according to Durkheim. See Terrier 2013, p. 136, on this topic.

${ }^{16}$ Durkheim 1991, p. 715.

${ }^{17}$ Durkheim 1973. Durkheim defines punishment as a passionate reaction of graduated intensity emanating from society and enforced through the intermediary of a constituted body.

${ }^{18}$ Durkheim 1973, p. 39.
} 
Mead shows us the other side of those emotions which Durkheim treats as straightforward functional, demonstrating their potential for destructive intolerance and escalating social violence $[\ldots]$ The passionate, punitive reactions which Durkheim describes are [...] those of religious zealots, and while deep religious commitment can form the basis for a stable social order, it can also give rise to intolerance, repression, schismatic division, and bitter social conflict. ${ }^{19}$

With Mead's help, we can understand how the passionate desire to punish can trigger both inclusion and exclusion mechanisms, thus establishing boundaries between 'us' and 'others'. We can imagine religion's contribution to the experience of punishment, using the Durkheimian perspective, as it has, in effect, helped to define the social rules. If these rules are, in part, linked with a policy model that has incorporated one or more religions, at the exclusion of others, this also creates boundaries between 'us' and 'others' at the religious level. This cultural context can also be one of religious diversity and, while one religious practice may be seen as useful for purposes of punishment and rehabilitation, another may not. The overlap between the social and the religious may seem apparent, but it is less so in a context of religious plurality.

\section{From Resurrection to Rehabilitation: Foucault and Religion's Role as a Mediator in Prison}

According to Michel Foucault's analysis (Foucault 1975) concerning the development of the prison system in France, roughly between 1750 and 1820, penance is interpreted as a technique of the exercise of power. In the Western world, violent physical punishment has gradually been replaced with another form of violence that is more subtle and can sometimes be psychological, but not exclusively so. The liberal discourse of the late eighteenth century jurisprudence in Europe saw the introduction of new criminal law and justice models that transformed prisons from places which held offenders until punishment was carried out (in the form of execution, or other physical acts), into places of detention and discipline. While this transformation is often viewed as a humanisation of criminal punishment, ${ }^{20}$ Foucault instead invites us to look beyond this perspective and regard these changes as a new means of social control, epitomised by the panopticon architecture adopted in some new prisons.

As Foucault clearly highlights, historical references to the architecture and codes of modern prisons focused on two essential religious elements: monasteries on the one hand and Protestant ethics on the other. The Eastern State Penitentiary in Philadelphia and the Auburn Prison in New York were paradigmatic embodiments of these two influences in the nineteenth century. The Catholic Church historically had its own prisons and rejected the rationalisation of punishment proposed by utilitarian thinkers like Benjamin Franklin or Cesare Beccaria. This model had a certain degree of success in the Catholic world which, according to Foucault, may be explained by the fact that the concept of resurrection is so relatable to prisoners. ${ }^{21}$ This metaphor, too, held its discursive power for a long time. To give an example, one might mention the (Catholic) Pope's yearly visit to prisoners during the Easter period in Italy, which is seen as a deeply symbolic event. ${ }^{22}$ Today, psychotherapy and rehabilitation models for prisoners use more secular and universal terms for the same process, referring to

\footnotetext{
${ }^{19}$ Garland 1990, p. 77. cfr. also Santoro 1997, p. 76.

${ }^{20}$ As in the case of the Philadelphia prison, designed by Quakers, see Ignatieff 1989.

${ }^{21}$ See Foucault 1975, p.242.

${ }^{22}$ Cf. Corriere della Sera, Roma, 28.3.2013. Giovedì Santo. Il Papa nel carcere minorile di Roma: «Il più alto sia al servizio degli altri». Last accessed: $1.12 .2013 \mathrm{http}: / /$ roma.corriere.it/roma/notizie/cronaca/13_marzo_28/papafrancesco-giovedi-santo-roma-212383480840.shtml
} 
'transformation' or 'change'. The Quakers (The Religious Society of Friends), who founded the philanthropic prison model in Philadelphia, promoted the idea that criminals could experience repentance in prison, that imprisonment could release them from their guilt and allow them to regenerate. In their view, the best way to promote this process was to isolate prisoners in individual cells - thereby breaking the link with negative elements which could draw people into a life of crime-while regulating hygienic conditions, religious instruction and work. By drawing a parallel between sin and crime, they offered criminals an internal means of repentance, visible only to the inner eye, or to God. The Philadelphia penitentiary became the paradigm for the concept of institutional rehabilitation. Its model was an unparalleled success in the Western world and has been called the 'most influential prison ever built'. ${ }^{23}$ From there, the image of the prison as a place of conversion began to take shape. Religion was clearly a part of the prison's overall aim and was considered useful to its achievement. Although state institutions in the three countries examined here sought autonomy vis-à-vis religion as their societies became more secular, some rhetoric concerning redemption and resurrection through repentance and spiritual conversion remained. ${ }^{24} \mathrm{~A}$ more secular understanding of this idea was popularised, and led to the promotion of rehabilitation through change, but the patterns remained similar. The chaplains - pastors or priests — played a central role in the new prisons. ${ }^{25}$ Often, the need for spiritual conversion was also linked to the notion of criminals as fundamentally irrational beings, as people who could not be rehabilitated through reason alone. Only religion was seen as the only thing that could work.

For Foucault, the development of the prison system was indicative of a broader process that pervades society as a whole: shifts in power strategies. With the establishment of such institutions, power is henceforth exercised through the discipline that pervades all spheres of human activity. Despite the limitations of his approach, Foucault's great contribution has been to draw attention to the infiltration of state power into the private sphere of the individual, his mind and attitudes.

If the penalty in its most severe forms no longer addresses itself to the body, on what does it lay hold? The answer from the theoreticians - those who, about 1760, opened up a period that is not yet at an end - is simple, almost obvious. Since it is no longer the body, it must be the soul. The expiation that once rained down upon the body must be replaced by a punishment that acts in depth on the heart, the thoughts, the will, the inclinations. $^{26}$

According to Foucault, to achieve this goal, states incorporated Christian religions into their expanding powers. On the one hand, religion was institutionally separated from other areas of prison life, for example, from work, health and education; while on the other hand, all institutional actors (i.e. chaplains, but also educators, therapists, social workers and security agents) were tasked with exercising a pastoral form of power. ${ }^{27}$ As Foucault reminds us, this technique implies the existence of a 'flock' that must be guided and led to 'salvation', and such power 'cannot be exercised without knowing the inside of people's minds, without exploring their souls, without making them reveal their innermost secrets. It implies a knowledge of the conscience'. ${ }^{28}$ This knowledge was ensured by such techniques as individual examinations, face to face meetings, the guiding of conscience and obedience.

\footnotetext{
23 Johnston 2000 [1994], p. 105.

24 The periods of Nazism in Germany, Fascism in Italy and the time of the two world wars more generally are exceptions to this.

${ }^{25}$ For Switzerland, see Roth 1981, p. 201-209.

${ }^{26}$ Foucault 1975, pp. 16 in the English translation.

${ }^{27}$ For a discussion on the concept of pastoral power in the prison context, see Becci 2007.

${ }^{28}$ Foucault, 1983, p. 218.
} 
In Foucault's approach focusing on the techniques utilised to ensure power, religious and secular instances are not opposed; both are part of individualising 'techniques' which are characteristic of the forms of power in state institutions. The continuity between a more religious and a secular form of power relates to what I referred to earlier as the process of universalisation of religion, which is part of secularisation. In his historical reconstruction, Foucault pays no real attention to the process that allowed churches, particularly after the Second World War, to assert some autonomy vis-à-vis states and thereby also to have the opportunity to resist the techniques of state power (see Becci 2010). Religion can be mobilised in order to discipline or liberate; to integrate or exclude. It all depends on the cultural context in question, which it contributes to shaping, and on the precise configuration of religious diversity. Therefore, in order to better understand this context, I now turn to my empirical findings.

\section{The Regulation of Religious Diversity in Swiss, German and Italian Prisons: Neutralisation} and Resistance

In this second part of the article, I will concentrate on comparative analysis of different prisons in Switzerland, Germany and Italy. As a first step, I will determine the prison institutions' level of understanding of religious diversity, in terms of statistical data. Secondly, I will explore the detainees' perspectives and analyse their references to religion and spirituality in their daily lives.

The prisons in the three countries in question are quite similar, to an extent, and in other ways, they are not alike. As shown in Table 1, a similar number of people are imprisoned in Italy and Germany, with significantly less in Switzerland. However, the amount of prisons in Switzerland, given its prison population, indicates that it has numerous small prisons. Other features of the prison population, such as the age of the prisoners or the occupancy rate, are roughly the same in Germany as in Switzerland, whereas Italian prisons are rather overcrowded, and the average age of inmates is higher. In all three countries, the proportion of female prisoners stands between 5 and $6 \%$. These socio-cultural traits, as well as others that were inaccessible to me on a statistical level (such as educational background, for instance), have strong implications for the religious situation in prisons. ${ }^{29}$

While some recent public and scientific studies have focused on the increase in non-native prisoners (Berry and Kuhn 1993), the religious issue has hardly been mentioned, except in relation to the increase in the number of Muslim inmates (Rhazzali 2010).

Not all prisons record the religious belongings of detainees in the same way. There is a centralised national census in Italy (Department for Penitentiary Administration), whereas in Germany, the regions play a more important role, and in Switzerland, each prison must ask prisoners about their religion upon entry. Table 2, which contains information collected from multiple sources, attempts to illustrate the huge variance between different prison institutions, even within the same country. Thus, a prison may have a very homogeneous population, from a religious point of view, or indeed a 'super diverse' population (Vertovec 2007). The diversity of the prison population varies to a great extent from one country to another. In post-socialist Germany, for instance, most inmates are German and do not belong to any religion; in Switzerland, we see prisoners from the same regions who belong to very different religions and, conversely, we find prisoners of different nationalities with the same religious beliefs. At a

\footnotetext{
${ }^{29}$ See Becci and Schneuwly Purdie 2012 for a comparative analysis of the religiosity of imprisoned persons according to gender. Other sources for the two tables were, for Italy: the Italian department for penitentiary administration (DAP), for Switzerland: the federal statistical office and information gathered in 2010 in a highsecurity prison for men in French-speaking Switzerland, a men's prison in German-speaking Switzerland, a mixed prison in French-speaking Switzerland and a detention centre for women in German-speaking Switzerland, for Germany: the national statistical office.
} 
Table 1 Characteristics of the imprisoned people in Italy, Germany and Switzerland

\begin{tabular}{|c|c|c|c|}
\hline $2011 / 2012$ & Switzerland & Germany & Italy \\
\hline $\begin{array}{l}\text { Total number of } \\
\text { detainees }\end{array}$ & $\begin{array}{l}6,065 \text { (78 per } 100,000 \\
\text { inhabitants) }\end{array}$ & $\begin{array}{l}60,067 \text { (97 per } 100,000 \\
\quad \text { inhabitants })\end{array}$ & $\begin{array}{l}66,695 \text { (109 per } 100,000 \\
\text { inhabitants) }\end{array}$ \\
\hline Foreign nationals & $\begin{array}{l}71 \% \text { (approx. } 22 \% \text { in the } \\
\text { general population) }\end{array}$ & $\begin{array}{l}11 \text { to } 45 \% \text { (approx. } 8.5 \% \\
\text { in the general population) }\end{array}$ & $\begin{array}{l}36 \% \text { (approx. } 7.5 \% \text { in } \\
\text { the general population) }\end{array}$ \\
\hline $\begin{array}{l}\text { Detainees under } \\
30 \text { years old }\end{array}$ & $40 \%$ & $40 \%$ & $25 \%$ \\
\hline $\begin{array}{l}\text { Number of } \\
\text { prisons }\end{array}$ & 114 & 186 & 206 \\
\hline $\begin{array}{l}\text { Average } \\
\text { occupancy rate }\end{array}$ & 91 & 92 & $146>$ \\
\hline $\begin{array}{l}\text { Proportion of } \\
\text { women }\end{array}$ & $5.3 \%$ & $5.5 \%$ & $6.3 \%$ \\
\hline
\end{tabular}

glance, the religious beliefs of the prison populations across different countries as represented in Table 2 enable us to clearly see that some religious minorities are over-represented in relation to the national populations. This table shows digital data from various sources (which, unfortunately, are often sketchy, unsystematic and not entirely reliable) on the religious affiliation of people in detention. Rather than establishing an average, it takes into account the variation from one institution to the next, to whatever extent is possible, and in fact shows evidence of a fairly complex situation. As well as the diversity of inmates' religious belongings, Table 2 also draws attention to the high number of people who gave no indication of their religious belonging or indicated that they held none.

The religious variance in this data in terms of belonging is even stronger when it comes to practice. Today, the following paradox can be observed: 'whereas the proportion of prisoners who register as adherents of no religion shows a continuous, rapid and steady increase, the demand for religious and pastoral care remains strong. ${ }^{30}$ The institutions I have observed in the three countries would suggest that religious practices and social and symbolic places for religious experience fall outside of as much as within the formal chaplaincy service. ${ }^{31}$ As emphasised by the literature on prison as a total institution, gaps can exist between the planned organisational function of a place and the way it is actually used by inmates: far more goes on in a prison corridor, for instance, than inmates simply milling around. Vice versa, prison chaplaincies not only engage in religious but also secular action, and a considerable amount of religious action also takes place outside of chaplaincy facilities. In Italy, for instance, Catholic chaplains co-exist with other religious actors such as Jehovah's Witnesses, while constantly pressuring institutions for adaptation (Fabbretti and Rosati 2012). In a Swiss women's prison, a group of nuns regularly spend a couple of months living as detainees. Taking detainees' perspectives and practices into account, and analysing not only their discourse but also their daily routines, for example, enables us to explore further dimensions of the concept of religion: prayers, rituals, discussions and readings. Thus, for example, in Switzerland, some forms of 'popular religiosity' (Knoblauch 2009) are quite common: tarot cards, esoteric and New Age books, yoga practice and voodoo rituals have had considerable success. In Italy, I observed various forms of superstitious behaviour relating to religious objects, such as crucifixes. The following is a quote from a young German inmate, describing a fellow inmate: 'There is a lot of death here - people who glorify death... that

\footnotetext{
$\overline{30}$ Beckford \& Gilliat 1998, p. 142 .

${ }^{31}$ See Becci and Knobel 2013.
} 
Table 2 The religious affiliations of the prison populations across different countries

\begin{tabular}{llll}
\hline Religious affiliations & $\begin{array}{l}\text { Switzerland } \\
(2010)^{32}\end{array}$ & $\begin{array}{l}\text { Germany } \\
(2011)\end{array}$ & Italy $^{33}$ \\
\hline $\begin{array}{l}\text { Roman Catholic } \\
\text { Orthodox Christian }\end{array}$ & Between 21 and 42\% & $9 \%$ (east) $-45.5 \%$ (west) & $69 \%$ \\
Protestant & - & & $4 \%$ \\
Muslim & Between 2 and 31\% & $0.3 \%$ \\
None & Between 5 and $57 \%$ & $8 \%$ (east)-38.8\% (west) & $14.5 \%$ \\
Atheist & Between 5 and $14 \%$ & Ca. $80 \%$ (east)-ca. $8 \%$ (west) & - \\
No indication & & & $0.6 \%$ \\
Buddhist, Jewish, Hindu, Anglican, & Between 5 and $11 \%$ & $<1 \%$ & $9.2 \%$ \\
$\quad$ Jehovah's Witnesses & & $<1 \%$ & $<0.1 \%$ each \\
Other & & $5 \%$ & $2 \%$ \\
\hline
\end{tabular}

is their belief. The person I am thinking about, his obsession, when he is released, is: [to wear a] black leather coat, [to carry] a stick with skull with two ribbons, a goatee... and to blow up a nightclub.' I was informed of such people on several occasions. When one hears this kind of story, it is easy to understand the concern on the part of the institution to neutralise religion and spirituality. Here, the Durkheimian overlap between the social and the religious, which a prison institution would ultimately prefer, is not present. The institution hence aims to neutralise religion by integrating it within the institutional structure, an aim that, to some extent, has been achieved. In the interviews I conducted with various religious actors and prisoners, religion was treated first and foremost as an individual resource with limited impact. This attitude is well illustrated by one prisoner's interesting description of spiritual care as 'a harmless form of psycho-therapy.'

As a general observation following from the individual cases, it seems that secularisation has simply been accepted, and the location of religion accommodated. The question remains as to how institutions have responded to pluralisation. In order to approach this question empirically, it is crucial that the scope of the research extends beyond the Christian chaplaincy. Through inmates' practices and discussions, one can come to a better understanding of the greater or lesser involvement of a variety of other religious and spiritual actors, such as Pentecostals, Muslims, Baptists, Buddhists, Kimbanguists, Jehovah's Witnesses, Salvationists, Hindus, Jews and Evangelicals. ${ }^{32}$ To understand the impact of the imbalance between more established and other religions in relation to the religious experience in prison more generally, I conclude with an analysis of some religious events observed in different prisons, that is, of festivities, gatherings or celebrations organised by religious actors.

\section{An Empirical Illustration Through Religious Events}

During my fieldwork in Germany in $2004,{ }^{33}$ I participated in various events organised by prison chaplains of different faiths, such as Bible reading groups and ritual celebrations. In Switzerland, I collected material concerning an ecumenical Christmas celebration, and the research team ${ }^{34}$ was a witness to an animation event which had been organised by an

\footnotetext{
32 See Becci and Knobel 2013, Fabbretti and Rosati 2012.

${ }^{33}$ Beyond direct observation, I also asked all interviewees to talk about religious events that had occurred while they were in prison. In Italy, I participated in secular events, such as the end of year party for the educational section. This material is not included in the analysis, since it is not related directly to this analysis.

34 This research team was made up of Claude Bovay, Brigitte Knobel, Mallory Schneuwly-Purdie and myself.
} 
evangelical community, different Muslim prayers during Ramadan and a Christmas theatre performance by members of the Salvation Army.

These events took place in different types of prisons located in a variety of areas, and each lasted for between 1 and $2 \mathrm{~h}$. The activities organised by the chaplains and the Salvation Army's Christmas theatre performance took place in sites which were specially equipped for these purposes (chapels or multi-purpose rooms). Except in the case of a Sunday celebration in a large chapel within a prison, where several prison officers were present, these events went unsupervised. All the events also had an aesthetic dimension: music, light and a variety of food gave the atmosphere an air of celebration. In some of the men's prisons, women volunteers were allowed to attend these religious events. The worship times were always preceded or followed by long conversation periods, occasionally including the consumption of food and beverages. Several inmates and officers were usually involved in the preparation and organisation of the events. For instance, one inmate was responsible for ringing bells for the various religious celebrations planned in different languages over the course of one weekend at a prison in Berlin. Bells were also rung before the Christmas celebration in a prison in Switzerland. On that particular occasion, I observed a revealing interaction between the prison officers and the Christian chaplain. The tone of the conversation between the prison staff and the Christian chaplain was friendly and slightly humourous, indicating their familiarity and respective positions within the institution. Comments made by both prison officers and inmates when they entered the room suggested the Christian religious service was perceived as an inoffensive, harmless event. Hence, when one of the chaplains arrived with his guitar case, an officer asked, laughingly, if he was carrying a truncheon, to which the chaplain answered that they were indeed organising an attack. When he reminded the officer to ring the bells just before 8 a.m., the latter responded jokingly, 'Careful! There will be a rush of crowds!' No crowd rushed in, but the bells could be heard by everyone in the facility, which was in itself unique compared with other prisons. When we left the chapel after the Christmas celebration, we met some inmates who had not attended the service. They greeted us and said mockingly, 'Damn, it's already over, we missed the celebration again!', and the chaplains responded with similar jokes.

The number of participants in these celebrations is actually rather small in comparison with the numbers that attend other recreational events, such as sports or social activities. ${ }^{35}$ The benign nature of these moments was recognised by the officers: in the prisons we observed in Switzerland, new prison officers were tasked with supervising the Sunday celebrations, which the experienced officers knew was an unnecessary task. However, the organisation of Ramadan prayers was carried out in a much less casual way, and stood out in contrast. There is great variance in relation to dedicated spaces for Muslim prayer from one prison to another: sometimes, the gym or another room is transformed into a meeting place for worship on specific occasions. The time allotted is strictly regulated. For Muslim inmates in the prisons observed in Switzerland, prayer time is deducted from activity periods, thus reducing inmates' capacity to earn money. Outside worship time, prisoners rarely have time left for other exchanges. The sermon we attended was very rushed, as reported in the field notes. Unlike all the other events, only Muslim prisoners were allowed to attend Muslim prayer services. ${ }^{36}$

In the Christian celebrations we observed, inmates could sometimes meet new people, including women. For the other religious events, however, the only people that did not 'belong' in the prison (that were not staff or inmates) were representatives of that specific

\footnotetext{
35 The attendance of the end of year event organised by the education team I observed in Italy was higher.

${ }^{36}$ It is important to note that this is not the case in all Swiss prisons. Some of them, in larger cities, do have more professionally organised spiritual care for Muslim inmates, but they are rare.
} 
religion. Furthermore, our observations revealed another striking difference between the event organised by the Christian chaplains and the other religious events. This difference was in the tone of the message being communicated by the ministers of the different faiths. In the Salvationist and Evangelical celebrations, the core message concerned the importance of recognising one's own sins and evil influences, and the need to return to the right path through a process of internal conversion and repentance. The sermons during Muslim prayers also usually emphasised the importance of good religious conduct as a means of influencing the most fundamental attitudes to life and human nature. The religious communication in these cases still falls within the frame of reference of 'salvation', to use Foucault's term, or change, to put it in a secular way. The overlap of the social and religion here happened because a religion provided a service for the punishment-rehabilitation complex. In a sense, this questioned the differentiation between these two functions.

In contrast to this type of moral communication, the message of the Christmas celebration organised by the Christian chaplaincy stood out. The central figure of the celebration was a shepherd attending the birth of Jesus, in the biblical narrative. The celebration encouraged prisoners to adopt the shepherd's perspective, thereby acknowledging their marginality, and concluded with a message of divine compassion for all marginalised people. Thus, both the message and the form of this celebration were more universal and ethical than confessional or particularly moral. ${ }^{37}$ The message was not connected to the punishment-rehabilitation complex. The deep integration of the established religions seemed to allow them a certain degree of autonomy and independence, as was expressed during this service.

\section{Conclusion}

The changes made to the provision of religious assistance in prisons in various European countries in recent years have been introduced against a background of increasing attention to the issue of religious diversity. However, institutional resistance is still apparent in relation to more fundamental changes, those that would not only take the diversity of the religious landscape into consideration but also endeavour to qualitatively modify the human relation to religion and spirituality. Religion in prison is usually thought of in a similar way as any other prison activity, based on a standard template of what is expected from those involved. Triangulating the empirical material with the detainees' perspectives allowed me to approach this issue, from the point of view of religious action, from 'below'. The results corroboratedand at times also invalidated - the standard vision. Apparently, the ways in which religion is mobilised by institutional actors, on the one hand, and detainees, on the other, are largely divergent. Issues of equal treatment or equal formal representation of religions in secular prison spaces are today part of a broader process of negotiation concerning the role of religion vis-à-vis the aims of prison institutions. Any possibility of religious activity is weighed against the institution's need to maintain stability. As Durkheim's and Foucault's insights indicate, from the earliest days of the modern prison institution, a certain social form of religion has been seen as a central element, nourishing a sense of accountability and fostering the rehabilitation of the inmates. The established Christian chaplaincies are in a unique position in this context, because their activity is valued as 'universal'. The 'universalisation' of Christian religion in prisons, which has clearly identifiable historical roots, leads to a 'neutralisation' of one specific (Christian) type of spiritual assistance, which becomes the template for all other religious interaction. In this respect, the level of religious diversity seen in

$\overline{{ }^{37} \text { For further analysis of the practice of Muslim prisons, please see Schneuwly Purdie } 2013 .}$ 
European prisons in recent years could potentially represent a real challenge not just for the previously unrepresented religions, which must adapt to the institution whether they wish to or not (see Bernts and Ajouaou's contribution to this volume), but also for the institutions themselves and for the established Christian chaplaincies. Clearly, the penal institution-as a state structure-is still linked to its Christian heritage. Recent transformations have not only brought Christianity to profile as a kind of lingua franca, a mediator positioned at a meso-level that crosses, but also reinforces boundaries between established and other religions.

\section{References}

Amiraux, V. (2012). État de la littérature. L'islam et les musulmans en Europe : un objet périphérique converti en incontournable des sciences sociales, Critique internationale, 3(56), 141-157.

Becci, I. (2007). Penser le pouvoir pastoral dans les prisons actuelles. In Cicchini, M. and Porret, M. (eds.), Les sphères du pénal avec Michel Foucault, pp. 237-250. Antipodes.

Becci, I. (2010). Tactiques religieuses dans les espaces carcéraux d'Allemagne de l'Est. Revue d'histoire des sciences humaines, 23, 141-156.

Becci, I. (2011). Religion's multiple locations in prison. Germany, Italy, Switzerland. Archives de Sciences Sociales des Religions, 153(1), 65-84.

Becci, I. (2012). Imprisoned religion. Transformations of religion during and after imprisonment in Eastern Germany. Farnham: Ashgate.

Becci, I., \& Knobel, B. (2013). La diversité religieuse en prison: entre modèles de régulation et émergence de zones grises (Suisse, Italie et Allemagne). In A.-S. Lamine (Ed.), Quand le religieux fait conflit. Désaccord, négociations ou arrangements (pp. 109-121). Rennes: Presses Universitaires.

Becci, I., \& Schneuwly-Purdie, M. (2012). Gendered religion in prison? Comparing imprisoned men and women's expressed religiosity in Switzerland. Women's Studies: An inter-disciplinary journal, 41(6), 706-727.

Becci, I., Bovay, C., Kuhn, A., Schneuwly Purdie, M., Knobel, B., Vuille, J. (2011). Enjeux sociologiques de la pluralité religieuse dans les prisons suisses- rapport final:http:/www.nfp58.ch/files/news/99_Schlussbericht Becci_fr.pdf.pdf

Beckford, J. A., \& Gilliat, S. (1998). Religion in prison: equal rites in a multi-faith society. Cambridge: Cambridge University Press.

Berger, P. (1990). The sacred canopy. Elements of a sociological theory of religion. New York, N.Y.: Anchor Books.

Berger, P. A. (1995). Anwesenheit und Abwesenheit. Raumbezüge sozialen Handelns, Berliner Journal für Soziologie, 1, 99-111.

Berry, C., \& Kuhn, A. (1993). Minorité immigrée et victimisation: le cas de la Suisse. Bulletin de Criminologie, $1,70-84$.

Casanova, J. (2013). Religious Associations, Religious Innovations and Denominational Identities in Contemporary Global Cities, p. 113-127. In I. Becci, M. Burchard, \& J. Casanova (Eds.), Topographies of faith : Religion in urban spaces. Leiden, Boston: Brill.

Clemmer, D. (1958). The society of captives. New York: Rinehart. 1949.

Combessie, P. (2009). Sociologie de la prison. Paris: La Découverte.

Douglas, M. (1987). How institutions think. London: Routledge and L. Kegan Paul.

Durkheim, É. (1973). Two laws of penal evolution. Econ Soc, 2(3), 285-308.

Durkheim, É. (1991). Les formes élémentaires de la vie religieuse. Paris: Livre de Poche. 1912.

Fabbretti, V., \& Rosati, M. (2012). L'assistenza religiosa in carcere. Diritti e diritto al culto negli istituti di pena del Lazio Rapporto di ricerca. Center for the study and documentation of religions and political institutions in Post-Secular Society, Rome.

Foucault, M. (1975). Surveiller et punir. Naissance de la prison. Paris: Gallimard.

Foucault, M. (1983). The Subject and Power. In H. Dreyfus \& P. Rabinow (Eds.), Michel Foucault: Beyond Structuralism and Hermeneutics (2nd ed., pp. 208-226). Chicago: The University of Chicago Press.

Garland, D. (1990). Punishment and modern society: A study in social theory. Chicago, Oxford: University of Chicago Press and Oxford University Press.

Garland, D. (2001a). The culture of control: crime and social order in contemporary society. Chicago: University of Chicago Press.

Garland, D. (2001b). Mass imprisonment: social causes and consequences. London: Sage. 
Goffman, E. (1968). Asylums. Essays on the social situation of mental patients and other inmates. Harmondsworth: Penguin.

Ignatieff, M. (1989). A just measure of pain: The penitentiary in the industrial revolution, 1750-1850. Harmondsworth: Penguin.

Johnston, N. (2000). Eastern State penitentiary: crucible of good intentions. Philadelphia: Philadelphia Museum of Art.

Knoblauch, H. (2009). Populäre Religion-Auf dem Weg in eine spirituelle Gesellschaft. Campus Verlag: Frankfurt am Main.

Knott, K. (2009). From locality to location and back again: a spatial journey in the study of religion, in the study of religion. Religion, 39, 154-160.

Maeder, C. (1995). In totaler Gesellschaft-Eine ethnographische Untersuchung zum offenen Strafvollzug. Bamberg: Difo Druck.

Mauss, M. (1950). Essai sur le don. Forme et raison de l'échange dans les sociétés archaïques. In Sociologie et Anthropologie (pp. 143-279). Paris: PUF. 1923-1924.

Mead, G.-H. (1918). The psychology of punitive justice. Am J Sociol, 23, 577-602.

Melossi, D. (1990). The state of social control: a sociological study of concepts of state and social control in the making of democracy. Cambridge: Polity.

Poggi, G. (2000). Durkheim. Oxford: Oxford University Press.

Rhazzali, M. K. (2010). L'Islam in carcere: l'esperienza religiosa dei giovani musulmani nelle prigioni italiane. Milan: FrancoAngeli.

Rostaing, C. (2006). La Compréhension sociologique de l'expérience carcérale, in Revue européenne des sciences sociales. Tome XLIV, N135, 29-43.

Roth, R. (1981). Pratiques penitentiaires et theorie sociale. L'exemple de la prison de Geneve, 1825-1862. Geneva: Droz.

Ruffini, F. (1975). Relazioni tra stato e chiesa: Lineamenti storici e sistematici. Bologna: Il Mulino.

Santoro, E. (1997). Carcere e società liberale. Torino: G. Giappichelli Editore.

Santoro, E. (2005). Castigo e delitto. In P. Giglioli (Ed.), Invito allo studio della società (pp. 69-100). Bologna: Il Mulino.

Schneuwly Purdie, M. (2013). Formating Islam versus mobilizing Islam in prison. evidence from the Swiss case, in Belhoul, S., Bleisch, P., Leueunberger, S., Tuner-Zanetti, A. (eds.). Debating Islam. Transcript.

Stolz, J., \& Baumann, M. (2009). La nouvelle Suisse religieuse. Risques et chances de sa diversité. Genève: Labor et Fides.

Sykes, G. M. (1958). The society of captives: a study of a maximum security prison. Princeton, NJ: Princeton University Press.

Terrier, J. (2013). Pluralität und Einheit : Zum Verhältnis von Pluralismus und Gesellschaftstheorie bei Émile Durkheim. In T. Bogusz \& H. Delitz (Eds.), Émile Durkheim. Soziologie - Ethnologie - Philosophie, 119147. Campus Verlag: Frankfurt//New York.

Tschannen, O. (1992). Les Théories de la sécularisation. Genève: Droz.

Vertovec, S. (2007). Super-diversity and its implications. Ethnic and Racial Studies, 30(6), 1024-1054.

Wacquant, L. (1999). Suitable enemies: foreigners and immigrants in the prisons of Europe. Punishment \& Society, 1(2), 215-222. October.

Wiesnet, E. (1980). Die verratene Versöhnung. Zum Verhältnis von Christentum und Strafe. Düsseldorf: Patmos Verlag.

Yuval-Davis, N. (2011). The politics of belonging: Intersectional contestations. Thousand Oaks, CA: SAGE Publications Ltd. 